\title{
Correlation and Path Analysis for Yellow Mosaic Virus Disease Resistance and Yield Improvement in Blackgram [Vigna mungo (L.) Hepper]
}

\author{
R. Suguna, P. Savitha* and C.R. Ananda Kumar
}

Department of Plant Breeding and Genetics, Tamil Nadu Agricultural University, Coimbatore, Tamil Nadu, India

*Corresponding author

\author{
A B S T R A C T
}

\begin{tabular}{|l|}
\hline Key w or d s \\
$\begin{array}{l}\text { Correlation and path } \\
\text { analysis, Yellow } \\
\text { mosaic virus. }\end{array}$ \\
\hline Article Info \\
\hline $\begin{array}{l}\text { Accepted: } \\
17 \text { September } 2017 \\
\text { Available Online: } \\
\text { 10 November } 2017\end{array}$ \\
\hline
\end{tabular}

Pulses are rich and the cheapest source of delivering protein and also valuable animal feed. Indian has the largest area of about $34 \%$ and total production of about $26 \%$ of pulses globally. The present investigation was carried out with four parents in Diallel mating design during 2010-2011. The resultant 12 hybrids and four parents were evaluated in a randomized and replicated trial for estimating with regard to seed yield, correlation, path analysis and YMV resistance. The study on association of different traits indicated that single plant yield was highly correlated with plant height, number of branches per plant, number of pods per plant, pod length and number of seeds per pod. Path analysis revealed that pod length followed by number of pods per plant and number of branches per plant will be effective in increasing the yield. The inheritance of YMV was studied with 12 hybrids, among the hybrids, VBN 4 x VBN 2, VBN $2 \times$ VBN 4 and VBN $2 \times$ LBG 17 showed complete resistance against YMV, hence the crosses were recommended for further breeding programme to identify high yielding YMV resistant lines.

\section{Introduction}

Blackgram [Vigna mungo (L.) Hepper] is an important grain legumes grown in many regions of India and in Asian countries like Pakistan, Bangladesh, Sri Lanka and Myanmar. In the developed countries, grain legumes are an important indirect source of protein. However, for many developing countries, pulses constitute the cheap and readily available source of dietary protein. Therefore, the only practical means of solving the protein malnutrition in developing countries is to increase the production of pulse crops. The pulse crops, in general, give lower yield than the cereal crops. One school of thought believes that, because pulses are rich in protein they require more energy to synthesize protein than carbohydrates. From the comparisons of known energy requirements of various metabolic pathways, one gram of glucose can give rise to $0.8 \mathrm{~g}$ carbohydrate but on an average, only about $0.5 \mathrm{~g}$ of protein. Besides this, pulse crops are generally cultivated in marginally poor soils, mostly in rainfed conditions which leads to low yield. While considering the area and production, it is found to be in the declining trend. Besides, the pulse crop, especially black gram, is attacked by more number of pests and diseases. Among the diseases, yellow mosaic virus disease (YMV) is the 
major causing yield loss up to 66.6 per cent (Chand and Verma, 1983). The grain legumes are noted for their low yielding capacities throughout the world. The reason for low yield of pulses is not only due to the reason aforesaid, it may rather be that they have not received enough attention concerning intensive breeding efforts. Of late only, the grain legumes drew the serious attention of plant breeders and many high yielding disease resistant varieties have been released from different states. Even then, still, more research and attempts are to be made to develop high yielding and disease resistant varieties so as to achieve self-sufficiency in pulses, especially in blackgram. In any crop improvement programme, the most important prerequisite is the selection of suitable parents, which could combine well and produce desirable segregants. In crops like blackgram, where hybridization followed by back cross or pedigree method is commonly followed, genetic information especially about the nature of combining ability and type of gene action governing the inheritance of economically important quantitative and qualitative traits like YMV resistance can be of immense help to the breeder in the choice of suitable parents and appropriate breeding procedures. The 'Diallel' analysis helps to find out the combining ability for different yield attributes and also the gene action involved. Yield is a complex character collectively influenced by various components. The correlation coefficients coupled with path coefficient estimates provides information on relative importance of the components of yield. Keeping these points in view, a study was undertaken in the present investigation to understand the complexity of quantitative as well as qualitative traits in blackgram. The materials selected for this study included three high yielding and YMV resistant varieties of blackgram and one is YMV susceptible. Yellow mosaic virus is one of the most important constraints for blackgram production. It was also noted on blackgram under natural condition in India (Williams et al., 1968). The virus is endemic to the South Asia region but occurs sporadically in Southeast Asia such as in Thailand where the virus was reported only from 1977 to 1981. Since it is a severe and widespread viral disease, it has been extensively studied by many investigations (Ahmad, 1975; Sandhu, 1978; Jalaluddin and Sheikh, 1981; Singh et al., 1988). The disease cause serious reduction in the yield of blackgram. It is reported to the extent of $85 \%, 62 \%$ and $43 \%$ in case of early mid and late inoculations, respectively. The reduction in yield is contributed by reduction in number of pods per plant, seeds per pod and seed weight (Singh and Srivastava, 1985). Due to YMV, the genetic variability is lost and it is this genetic potential for high yield needs to be regenerated. The state and National programme on the improvement of pulses emphasized the urgency of generating variability for high genetic potential. Investigation on the magnitude of heterosis helps to identify promising hybrid combination and also possible to exploit to new recombinant type for yield and it's attributing traits from segregants.

\section{Materials and Methods}

The present investigation was conducted at the Agricultural College and Research Institute, Madurai during 2010-2011 at the experimental farm in the Department of Plant Breeding and Genetics. Four varieties of blackgram obtained from National Pulses Research Centre, Vamban, Tamil Nadu. Among the parents, four genotypes viz., Vamban 4, Vamban 2, LBG 17 and CO 5 were used as the materials of the present study. Twelve hybrids were raised during Rabi, 2011 in ridges of three meter length with an inter row spacing of $40 \mathrm{~cm}$ and intra- 
row spacing of $20 \mathrm{~cm}$. The hybrids were raised in a Randomized Block Design with three replications. For estimating heterosis, the parents were also raised in adjacent plot with above mentioned spacing in three replications. The recommended agronomic and plant protection practices were followed to maintain healthy stand of the plants. The Yellow Mosaic Virus Disease (YMV) incidence was recorded on all the plants based on the visual scores on $50^{\text {th }}$ day while the susceptible check C0 5 recorded scale 6.9. The classification was made into scales $1-9$ as follows based on the scale adopted by Singh et al., (1988) (Table 5 and 6). Combining ability analysis of cultivars is thus important to exploit the relevant type of gene action for a breeding programme. Combining ability estimates can be used to evaluate the number of promising lines in $F_{1}$ and $F_{2}$ generations, which is quite helpful in selecting the potential parents for hybridization. Combining ability study is useful in classifying the parental lines in terms of their hybrid performance (Dhillon, 1975). It also helps in identifying the parents suitable for hybridization programme and deciding suitable breeding methodology.

\section{Results and Discussion}

The analysis of variance of RBD for 12 hybrids and four parents separately revealed highly significant difference among the genotypes for 11 traits studied (Table 1 and 2). Since all the traits showed highly significant difference among the genotypes, the combining ability effects of parents and their $F_{1}$ hybrids were estimated by the diallel method of analysis.

\section{Correlation studies}

The genotypic correlation coefficients between grain yield and its component characters and inter correlation among different traits are presented in Table 3 . In the present study, single plant yield expressed significant and positive association with number of branches per plant, pod length, plant height, number of pods per plant, number of seeds per pod, 100 grain weight, number of clusters per plant, days to 50 percent flowering and protein content. This result was in close agreement with those obtained by earlier workers viz., Chauhan et al., (2007), Konda et al., (2008), Mallikarjuna Rao et al., (2006), Haritha and Sekhar (2002), Anbumalarmathi (2002), Vijiyalaxmi and Bhattacharya (2006) Rahim et al., (2010) and Pushpa Reni et al., (2013) for days to 50 per cent flowering, days to maturity and protein content. Single plant yield expressed highly significant and positive association with number of branches per plant (0.858), pod length (0.694), plant height (0.692) number of pods per plant (0.641), number of seeds per pod (0.631). Hundred grain weight (0.554), number of clusters per plant $(0.531)$, days to 50 per cent flowering (0.506) and protein content (0.435) registered significantly positive correlation. Days to 50 per cent flowering showed positive and highly significant correlation with days to maturity (0.804). The remaining characters viz., protein content (0.527), number of pods per plant (0.500), plant height (0.470) and number of branches per plant $(0.466)$ showed positive and significant correlation. The inter correlation between yield contributing characters may affect the selection for component traits either in favourable or unfavourable direction. Hence, the knowledge on inter relationship between yield component traits may facilitate breeders to decide upon the intensity and direction of selection pressure to be given on related traits for the simultaneous improvement of these traits.

Days to maturity had with showed significant and positive correlation pod length (0.676), protein content $(0.632)$, number of seeds per 
pod (0.615), number of pods per plant (0.604), number of branches per plant (0.594) and plant height (0.580) while with number of cluster per plant (0.483) exhibited significantly positive correlation. Plant height had significant and positive correlation with number of seeds per pod (0.829), pod length (0.806), number of branches per plant (0.773), number of pods per plant (0.712) and 100 grain weight $(0.683)$. There was a positive and significant correlation between plant height with number of branches per plant and all other character except number of clusters per plant and protein content. These results were in close agreement with the findings of Rahim et al., (2010) for number of pods per plant, Sunil kumar et al., (2003) for pod length, Mallikarjuna Rao et al., (2006), Baudh Bharti et al., (2014) for number of seeds per pod.

Number of branches per plant had significant positive association with pod length (0.838), number of pods per plant (0.795), number of clusters per plant (0.779), number of seeds per pod (0.681), hundred grain weight (0.648) and protein content $(0.547)$.

Number of branches per plant had highly significant and positive correlation with number of clusters per plant, pod length, number of pods per plant, number of seeds per pod, 100 grain weight and protein content. This was supported by Natarajan and Rathinasamy (1999) for number of cluster per plant and Mallikarjuna Rao et al., (2006) for number of pods per plant and number of seeds per pod. Konda et al., (2008), Sheetal et al., (2014) for protein content.

Number of clusters per plant expressed positive and significant correlation with number of pods per plant (0.666), pod length (0.626) and number of seeds per pod (0.508). Number of clusters per plant expressed significantly positive correlation with number of pods per plant, pod length and number of seeds per pod. These results were in close agreement with the findings of Kasundra et al., (1995) for number of seeds per pod, Sunil Kumar et al., (2003) for number of pods per plant, Konda et al., (2008), Kanimoli Mathi Vathana et al., (2015) for pod length.

Pod length showed positive and significant association with number of seeds per pod (0.976), number of pods per plant (0.616) and 100 grain weight (0.459). Pod length had significantly positive association with number of pods per plant, number of seeds per pod and 100 grain weight.

This was earlier found by Gayen and Chattopodhayay (2002) for number of seeds per pod and 100 grain weight. Number of pods per plant showed significantly positive association with plant height, number of seeds per pod and 100 grain weight. This was supported by Santha and Velusamy (1997) for plant height, Sunil Kumar et al., (2003) and Konda et al., (2008) for number of seeds per pod. Number of seeds per pod had registered significant and positive association with 100 seed weight. Number of pods per plant had positive and significant correlation with 100 grain weight (0.843) and number seeds per pod (0.572) showed significantly positive correlation. Number of seeds per pod registered positive and significant association with 100 grain weight (0.506). Hundred grain weights had positive and non-significant correlation with protein content $(0.281)$.

\section{Path coefficient analysis}

The direct and indirect effects of 11 characters on single plant yield are presented in Table 4. A brief account on direct and indirect effects on different component traits on grain yield is presented below. The direct effects of characters on the yield are presented in Figure 1. 
Table.1 Analysis of variance of RBD for different traits in parents and hybrids

\begin{tabular}{|c|c|c|c|c|c|c|c|c|c|c|c|c|}
\hline \multirow[b]{2}{*}{ Source } & \multirow[b]{2}{*}{ d.f } & \multicolumn{11}{|c|}{ Mean squares } \\
\hline & & DF & DM & PH & BR & CPP & PL & PPP & SPP & HS & PRT & YLD \\
\hline Replication & 2 & 18.08 & 24.33 & 26.58 & 1.45 & 4.59 & 0.62 & 22.50 & 1.13 & 0.07 & 15.34 & 3.70 \\
\hline Parents & 3 & $4.56 * *$ & $124.97 * *$ & $101.81 * *$ & $0.82 * *$ & $10.77 * *$ & $0.39 * *$ & $132.52 * *$ & $0.82 * *$ & $0.98 * *$ & $9.06 * *$ & $4.34 * *$ \\
\hline Hybrids & 11 & $1.76 * *$ & $16.93 * *$ & $68.06 * *$ & $0.58 * *$ & $16.41 * *$ & $0.51 * *$ & $144.51 * *$ & $0.32 *$ & $0.73 * *$ & $9.42 * *$ & $34.39 * *$ \\
\hline Treatment & 15 & $2.20 * *$ & $40.83 * *$ & $94.66 * *$ & $0.71 * *$ & $29.94 * *$ & $0.47 * *$ & $67.59 * *$ & $0.40^{*}$ & $0.68 *$ & $6.32 * *$ & $44.22 * *$ \\
\hline Error & 30 & 0.43 & 0.55 & 0.21 & 0.09 & 0.22 & 0.67 & 0.02 & 0.16 & 0.10 & 0.20 & 0.16 \\
\hline
\end{tabular}

*Significant at 5\% level ** Significant at $1 \%$ level $\mathrm{DF}$ - Days to 50 per cent flowering DM - Days to maturity

PH - Plant height

BR - Number of branches per plant CPP - Number of clusters per plant PL - Pod length SPP - Number of seeds per pod

HS - Hundred seed weight

PRT - Protein content

PPP - Number of pods per plant

YLD - Seed yield per plant

Table.2 Analysis of variance of combining ability for different traits

\begin{tabular}{|c|c|c|c|c|c|c|c|c|c|c|c|c|}
\hline \multirow[b]{2}{*}{$\begin{array}{c}\text { Source } \\
\text { of } \\
\text { variatio } \\
\text { n }\end{array}$} & \multirow[b]{2}{*}{ d.f } & \multicolumn{11}{|c|}{ Mean squares } \\
\hline & & \begin{tabular}{|c} 
Days to \\
50 per \\
cent \\
flowerin \\
g
\end{tabular} & $\begin{array}{c}\text { Days to } \\
\text { maturit } \\
y\end{array}$ & $\begin{array}{c}\text { Plant } \\
\text { height }\end{array}$ & $\begin{array}{c}\text { No. of } \\
\text { branche } \\
\text { s per } \\
\text { plant }\end{array}$ & $\begin{array}{c}\text { No. of } \\
\text { clusters } \\
\text { per } \\
\text { plant }\end{array}$ & $\begin{array}{c}\text { No. of } \\
\text { pods per } \\
\text { plant }\end{array}$ & $\begin{array}{c}\text { Pod } \\
\text { length }\end{array}$ & $\begin{array}{c}\text { Number } \\
\text { of seeds } \\
\text { per pod }\end{array}$ & $\begin{array}{c}100 \text { grain } \\
\text { weight }\end{array}$ & $\begin{array}{l}\text { Protein } \\
\text { content }\end{array}$ & $\begin{array}{c}\text { Single } \\
\text { plant yield }\end{array}$ \\
\hline GCA & 3 & $3.08 * *$ & $38.93 * *$ & $70.16^{* *}$ & $0.25 * *$ & $3.85 * *$ & $51.90 * *$ & $0.27 * *$ & 0.56 & $0.19 * *$ & $1.40 * *$ & $23.12 * *$ \\
\hline SCA & 6 & 0.23 & $11.77 * *$ & $25.17 * *$ & $0.38 * *$ & $16.73 * *$ & $18.36 * *$ & $0.23 * *$ & $0.18^{*}$ & $0.21 * *$ & $2.05 * *$ & $21.43 * *$ \\
\hline RCA & 6 & 0.065 & $2.78 * *$ & $18.63 * *$ & $0.08 *$ & $6.29 * *$ & $12.00 * *$ & $0.02 *$ & 0.12 & $0.26^{* *}$ & $2.51 * *$ & $3.85 * *$ \\
\hline Error & 30 & 0.14 & 0.18 & 0.07 & 0.03 & 0.07 & 0.22 & 0.00 & 0.05 & 0.03 & 0.06 & 0.05 \\
\hline
\end{tabular}

* Significant at 5\% level, ** Significant at $1 \%$ level 
Table.3 Genotypic correlation coefficients between single plant yield and component characters

\begin{tabular}{|c|c|c|c|c|c|c|c|c|c|c|c|}
\hline Characters & $\begin{array}{c}\text { Days to } 50 \\
\text { per cent } \\
\text { flowering }\end{array}$ & $\begin{array}{l}\text { Days to } \\
\text { maturity }\end{array}$ & $\begin{array}{c}\text { Plant } \\
\text { height }\end{array}$ & $\begin{array}{c}\text { No. of } \\
\text { branches } \\
\text { per plant }\end{array}$ & $\begin{array}{c}\text { No. of } \\
\text { clusters } \\
\text { per plant }\end{array}$ & $\begin{array}{c}\text { Pod } \\
\text { length }\end{array}$ & $\begin{array}{c}\text { No. of } \\
\text { pods per } \\
\text { plant }\end{array}$ & $\begin{array}{c}\text { No. of } \\
\text { seeds per } \\
\text { pod }\end{array}$ & $\begin{array}{c}100 \\
\text { grain } \\
\text { weight }\end{array}$ & $\begin{array}{l}\text { Protein } \\
\text { content }\end{array}$ & $\begin{array}{c}\text { Single } \\
\text { plant } \\
\text { yield }\end{array}$ \\
\hline Days to 50 per cent flowering & 1.000 & $0.804 * *$ & $0.470 *$ & $0.466^{*}$ & 0.215 & 0.357 & $0.500 *$ & 0.352 & 0.420 & $0.527 *$ & $0.506 *$ \\
\hline Days to maturity & & 1.000 & $0.580 * *$ & $0.594 * *$ & $0.483 *$ & $0.676^{* *}$ & $0.604 * *$ & $0.615^{* *}$ & 0.417 & $0.632 * *$ & 0.400 \\
\hline Plant height & & & 1.000 & $0.773 * *$ & 0.361 & $0.806^{* *}$ & $0.712 * *$ & $0.829 * *$ & $0.683 * *$ & 0.416 & $0.692 * *$ \\
\hline No. of branches per plant & & & & 1.000 & $0.779 * *$ & $0.838 * *$ & $0.795 * *$ & $0.681 * *$ & $0.648 * *$ & $0.547 * *$ & $0.858 * *$ \\
\hline No. of clusters per plant & & & & & 1.000 & $0.626 * *$ & $0.666^{* *}$ & $0.508^{*}$ & 0.224 & 0.251 & $0.531^{*}$ \\
\hline Pod length & & & & & & 1.000 & $0.616^{* *}$ & $0.976 * *$ & $0.459 *$ & 0.421 & $0.694 * *$ \\
\hline No. of pods per plant & & & & & & & 1.000 & $0.572 *$ & $0.843 * *$ & 0.362 & $0.641 * *$ \\
\hline No. of seeds per pod & & & & & & & & 1.000 & $0.506 *$ & 0.311 & $0.631 * *$ \\
\hline 100 grain weight & & & & & & & & & 1.000 & 0.281 & $0.554^{*}$ \\
\hline Protein content & & & & & & & & & & 1.000 & $0.435^{*}$ \\
\hline
\end{tabular}

* Significant at $5 \%$ level, ** Significant at $1 \%$ level

Table.4 Direct and indirect effect of different characters on yield

\begin{tabular}{|c|c|c|c|c|c|c|c|c|c|c|c|}
\hline Characters & $\begin{array}{l}\text { Days to } 50 \text { per } \\
\text { cent flowering }\end{array}$ & $\begin{array}{l}\text { Days to } \\
\text { maturity }\end{array}$ & $\begin{array}{c}\text { Plant } \\
\text { height }\end{array}$ & $\begin{array}{c}\text { No. of } \\
\text { branches per } \\
\text { plant }\end{array}$ & $\begin{array}{c}\text { No. of } \\
\text { clusters per } \\
\text { plant }\end{array}$ & $\begin{array}{c}\text { Pod } \\
\text { length }\end{array}$ & $\begin{array}{c}\text { No. of } \\
\text { pods per } \\
\text { plant }\end{array}$ & $\begin{array}{c}\text { No. of } \\
\text { seeds } \\
\text { per pod }\end{array}$ & $\begin{array}{c}100 \\
\text { grain } \\
\text { weight }\end{array}$ & $\begin{array}{l}\text { Protein } \\
\text { content }\end{array}$ & $\begin{array}{c}\text { Single } \\
\text { plant } \\
\text { yield }\end{array}$ \\
\hline $\begin{array}{l}\text { Days to } 50 \text { per } \\
\text { cent flowering }\end{array}$ & 1.014 & -1.064 & -0.216 & 0.228 & -0.103 & 0.466 & 0.447 & -0.046 & -0.209 & 0.088 & $0.506^{*}$ \\
\hline Days to maturity & 0.815 & -1.044 & -0.267 & 0.291 & -0.232 & 0.882 & 0.540 & -0.080 & -0.208 & 0.106 & 0.400 \\
\hline Plant height & 0.476 & -0.839 & -0.460 & 0.378 & -0.173 & 1.051 & 0.636 & -0.108 & -0.340 & 0.069 & $0.692 * *$ \\
\hline $\begin{array}{l}\text { No. of branches } \\
\text { per plant }\end{array}$ & 0.472 & -0.860 & -0.356 & 0.489 & -0.373 & 1.094 & 0.711 & -0.088 & -0.322 & 0.091 & $0.858 * *$ \\
\hline $\begin{array}{l}\text { No. of clusters } \\
\text { per plant }\end{array}$ & 0.218 & -0.699 & -0.166 & 0.381 & -0.479 & 0.817 & 0.596 & -0.066 & -0.111 & 0.042 & $0.531 *$ \\
\hline Pod length & 0.362 & -0.978 & -0.371 & 0.410 & -0.300 & 1.034 & 0.551 & -0.127 & -0.228 & 0.070 & $0.694 * *$ \\
\hline $\begin{array}{l}\text { No. of pods per } \\
\text { plant }\end{array}$ & 0.507 & -0.874 & -0.327 & 0.389 & -0.319 & 0.803 & 0.894 & -0.074 & -0.419 & 0.061 & $0.641 * *$ \\
\hline $\begin{array}{l}\text { No. of seeds per } \\
\text { pod }\end{array}$ & 0.357 & -0.890 & -0.382 & 0.333 & -0.243 & 1.027 & 0.511 & -0.130 & -0.251 & 0.052 & $0.631 * *$ \\
\hline 100 grain weight & 0.426 & -0.604 & -0.314 & 0.317 & -0.107 & 0.599 & 0.754 & -0.066 & -0.497 & 0.047 & $0.554^{*}$ \\
\hline Protein content & 0.535 & -0.915 & -0.191 & 0.268 & -0.120 & 0.549 & 0.324 & -0.040 & -0.140 & 0.106 & $0.435^{*}$ \\
\hline
\end{tabular}

Residual effect: 0.16 
Table.5 Yellow Mosaic Virus disease (YMV)

\begin{tabular}{|c|l|l|}
\hline Scales & Percentage of plant foliage affected & Reaction \\
\hline 1 & Mottling of leaves covering 0.1 to 5.0 per cent of the leaf area. & Resistant \\
\hline 3 & Mottling of leaves covering 5.1 to 10.0 per cent of the leaf area. & Moderately resistant \\
\hline 5 & Mottling and yellow discoloration of 10.1 to 25.0 per cent of the leaf area. & $\begin{array}{l}\text { Moderately } \\
\text { susceptible }\end{array}$ \\
\hline 7 & Mottling and yellow discoloration of 25.1to 50.0 per cent of the leaf area. & Susceptible \\
\hline 9 & $\begin{array}{l}\text { Severe yellow mottling on more than 50.0 per cent and up to 100 per cent } \\
\text { of the leaf area. }\end{array}$ & Highly susceptible \\
\hline
\end{tabular}

Table.6 YMV scores in parents and hybrids

\begin{tabular}{|c|c|c|c|}
\hline Code no. & Genotypes & Mean YMV score & Reaction \\
\hline $\mathrm{P} 1$ & Vamban 4 & 1.0 & Resistant \\
\hline $\mathrm{P} 2$ & Vamban 2 & 1.0 & Resistant \\
\hline P3 & LBG 17 & 3.8 & Moderately resistant \\
\hline $\mathrm{P} 4$ & $\mathrm{CO} 5$ & 9.0 & Highly Susceptible \\
\hline \multicolumn{4}{|l|}{ Hybrids } \\
\hline P1 x P2 & VBN4 x VBN2 & 1.2 & Resistant \\
\hline P1 X P3 & VBN4 X LBG 17 & 4.3 & Moderately resistant \\
\hline P1X P4 & VBN4 X CO 5 & 3.8 & Moderately resistant \\
\hline $\mathrm{P} 2 \mathrm{X}$ P1 & VBN2 X VBN 4 & 1.8 & Resistant \\
\hline P2 X P3 & VBN2 X LBG 17 & 3.4 & Moderately resistant \\
\hline P2 X P4 & VBN2 X CO 5 & 7.6 & Susceptible \\
\hline P3 X P1 & LBG 17 X VBN 4 & 4.2 & Moderately resistant \\
\hline P3 X P2 & LBG 17 X VBN 2 & 1.5 & Resistant \\
\hline P3 X P4 & LBG 17 X CO5 & 5.8 & Moderately susceptible \\
\hline P4 X P1 & CO 5 X VBN4 & 4.2 & Moderately resistant \\
\hline $\mathrm{P} 4 \mathrm{X} \mathrm{P} 2$ & $\mathrm{CO} 5 \mathrm{X}$ VBN 2 & 4.5 & Moderately resistant \\
\hline P4 X P3 & C0 5 X LBG 17 & 9.2 & Highly Susceptible \\
\hline
\end{tabular}


Fig.1 Different effects of different characters on single plant yield

Fig. 9. Direct effect of different characters on single plant yield

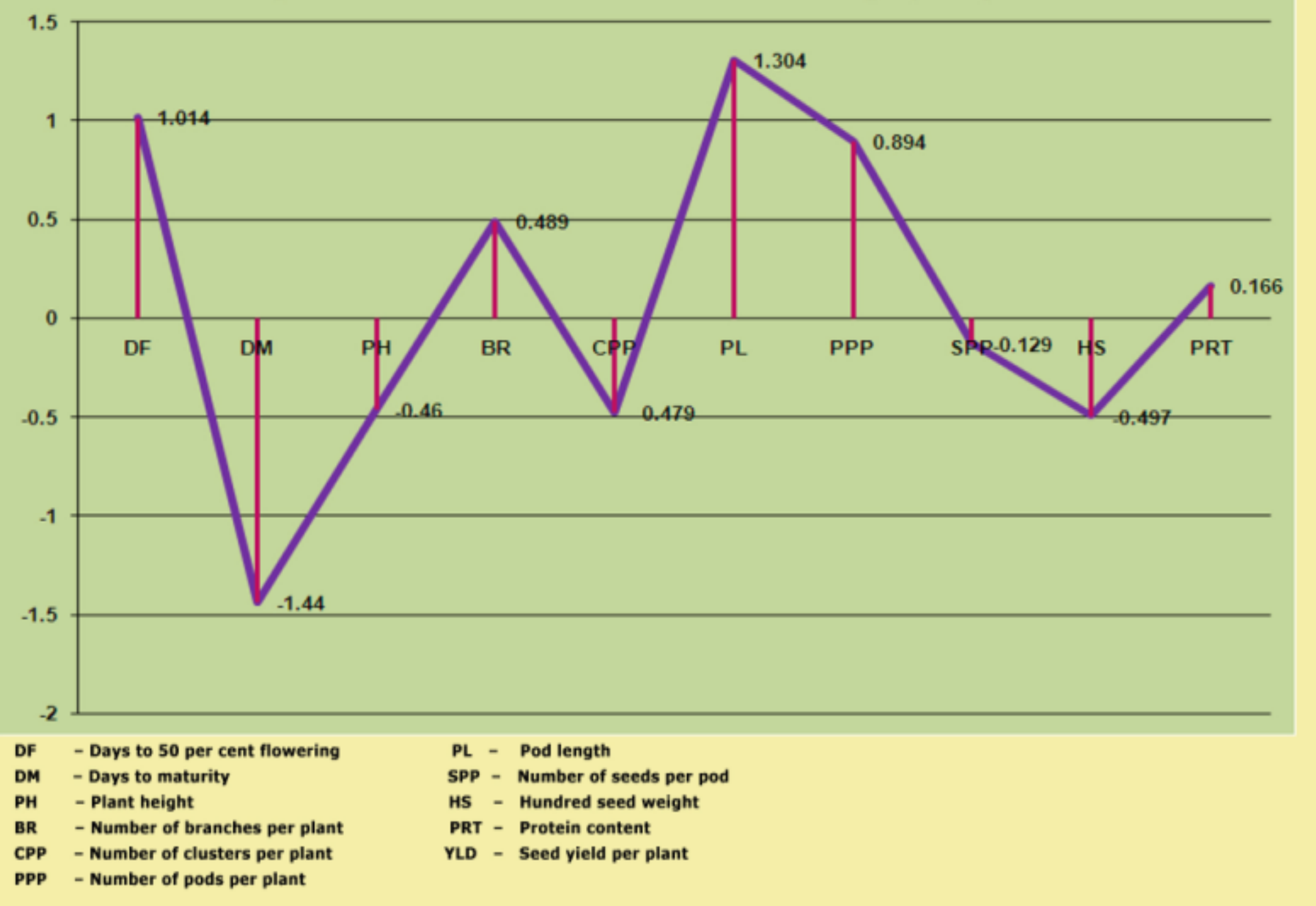




\section{Direct effects}

Days to 50 per cent flowering (1.014), pod length (1.304) had positive direct effect on single plant yield. Number of pods per plant (0.894), number of branches per plant (0.489) recorded moderate positive direct effects on single plant yield. In the present study, pod length had high direct effect on seed yield. This was in accordance with earlier findings of Konda et al., (2008), Kousar makeen et al., (2009) and Sunil kumar et al., (2003). Moderate direct effect on seed yield was noticed for number of pods per plant. It was suggested by Srividhya et al., (2005 b), Chauhan et al., (2007), Reena Mehra et al., (2016). Protein content (0.166) showed low positive direct effect on single plant yield. Days to maturity (-1.447), 100 grain weight (0.497), number of clusters per plant (-0.479) plant height (-0.460) and number of seeds per pod $(-0.129)$ had negative direct effects on single plant yield.

\section{Indirect effects}

Days to 50 per cent flowering recorded high negative indirect effect on single plant yield through days to maturity (-1.164). The indirect effects of days to 50 per cent flowering on grain yield was significant and positive through number of pods per plant (0.447), pod length (0.466), number of branches per plant $(0.228)$ and protein content (0.088). Negative indirect effect on yield through plant height (-0.126), number of clusters per plant $(-0.103)$ and 100 grain weight $(-0.209)$. Days to maturity showed negative negligible indirect effect through number of seeds per pod $(-0.080)$. Negative indirect effect through plant height $(-0.267)$, number of cluster per plant (-0.232) and 100 grain weight $(-0.208)$. Positive indirect effect through days to 50 per cent flowering (0.815), number of pods per plant (0.540), number of branches per plant (0.291) and protein content
(0.106) and also positive high indirect effect through pod length (0.882) on single plant yield.

Plant height showed high positive indirect effect on single plant yield through pod length (1.051), number of pods per plant (0.636), days to 50 per cent flowering (0.476), number of branches per plant (0.378) and protein content (0.069). Negative indirect effect through days to maturity $(-0.839), 100$ grain weight (-0.340), number of clusters per plant $(-0.173)$ and number of seeds per pod $(-0.108)$ on single plant yield. Number of branches per plant expressed high and positive indirect effect on yield through pod length (1.094). The indirect effect of number of branches per plant on grain yield was significant and positive through number of pods per plant (0.711) and days to 50 per cent flowering (0.472). Low and positive indirect effect on yield through protein content (0.091) via low and negative indirect effect through days to maturity (-0.860), number of cluster per plant (-0.373), plant height (-0.356) and 100 grain weight $(-0.322)$ on single plant yield. Number of branches per plant showed low positive direct effect on yield. Luman Hakim (2008) found similar results with regard to number of branches per plant. Remaining traits noticed negligible effect on single plant yield.

High positive indirect effect of number of clusters per plant on single plant yield was through pod length (0.817). Low and positive indirect effect on yield through number of pods per plant (0.596), number of branches per plant (0.381), days to 50 percent flowering (0.218) and protein content (0.042). Its indirect effect through days to maturity ($0.699)$, plant height (-0.166), 100 grain weight $(-0.111)$ and number of seeds per pod $(-0.066)$ was low and negative and through other traits was negligible. Pod length expressed positive and high indirect effect on single plant yield through number of pods per 
plant (0.551),number of branches per plant (0.410) and days to 50 per cent flowering (0.362) and Moderate and negative indirect effects through days to maturity $(-0.978)$ via rest of the traits with negligible values. The indirect effect of pod length and number of pods per plant on grain yield was positive through number of clusters per plant. The indirect effect of pod length was positive through number of pods per plant. The indirect effect of number of pods per plant and pod length was positive through 100 grain weight. Similar findings were also reported by Veeramani et al., (2005) Pushpa Rani et al., (2013) and Vijay kumar et al., (2015). The remaining traits had negligible effects on seed yield.

Positive and high indirect effect of number of pods per plant was noticed through pod length (0.803). Positive and moderate indirect effect days to 50 per cent flowering (0.507) and number of branches per plant (0.389). Negative and high indirect effect through days to maturity (-0.874), 100 grain weight ($0.419)$, plant height $(-0.327)$ and other traits showed negligible indirect effect on single plant yield. Number of seeds per pod expressed positive and high indirect effect on single plant yield through pod length (1.027).Positive and moderate indirect effect number of pods per plant (0.511), days to 50 percent flowering (0.357) and number of branches per plant (0.333). Negative indirect effect on yield through days to maturity (0.890) and negligible through rest of the traits. Hundred grain weight recorded positive and high indirect effect on single plant yield through number of pods per plant (0.754), pod length (0.599) and days to 50 percent flowering (0.426). Negative and low indirect effect on yield through days to maturity (0.604) via rest of the traits with negligible values. The indirect effect of protein content on single plant yield was high and positive effect through pod length (0.549), days to 50 percent flowering (0.535), number of pods per plant (0.324) and number of branches per plant (0.268). Negative and moderate indirect effect through days to maturity (-0.915). Plant height (-0.191), 100 grain weight $(-0.140)$ and number of cluster per plant $(-0.120)$ shows low and negative indirect effect. The study on association of different traits indicated that single plant yield was highly correlated with plant height, number of branches per plant, number of pods per plant, pod length and number of seeds per pod. Path analysis revealed that pod length followed by number of pods per plant and number of branches per plant will be effective in increasing the yield.

\section{Yellow mosaic virus disease (YMV) resistance}

According to the classification, scale 1-9 i.e. resistant, moderately resistant, moderately susceptible, susceptible, highly susceptible are discussed hereunder: Among the 12 crosses, three hybrids showed complete resistance against YMV with high yield performace. The hybrids are VBN 4 x VBN 2, VBN $2 \times$ VBN 4 and VBN $2 \times$ LBG 17. So the segregants from these crosses may be utilized for recombination breeding for hybridization and YMV resistant. Four hybrids reacted as moderately resistant to YMV such as VBN $4 \times$ LBG 17, VBN $2 x$ CO 5, LBG 17 x VBN 4 and CO 5 x VBN 2. Moderately susceptible reactions recorded by the hybrids were VBN 4 x CO5, LBG 17 x CO 5 and CO $5 \times$ VBN 4. The hybrids viz., LBG $17 \times$ VBN 2 and CO $5 \times$ LBG 17 was the two crosses showing susceptible reaction against YMV. Screening of parents and hybrids for reaction against yellow mosaic virus is presented in Table 5. Similar results were also reported by Shamim et al., (2014) and Peeta et al., (2016). Among the parents $\mathrm{P}_{1}$ and $\mathrm{P}_{2}$ were resistance to $\mathrm{YMV} \mathrm{P}_{3}$ is moderately resistance and $\mathrm{P}_{4}$ is susceptible to YMV. Experimental results clearly indicated 
that the crosses were rated as resistant to highly susceptible by using mean YMV score value. Out of 12 crosses, three crosses viz., $\mathrm{P}_{1}$ x $\mathrm{P}_{2}, \mathrm{P}_{2} \times \mathrm{P}_{1}$ and $\mathrm{P}_{2} \times \mathrm{P}_{3}$ showed resistance against YMV disease which gives more yield. Four hybrids reacted against YMV as moderately resistant which also gave more yield when compared to susceptible crosses. The crosses were $\mathrm{P}_{1} \times \mathrm{P}_{3}, \mathrm{P}_{2} \times \mathrm{P}_{4}, \mathrm{P}_{3} \times \mathrm{P}_{1}$ and $\mathrm{P}_{4} \quad \mathrm{x} \quad \mathrm{P}_{2}$. Similar result was reported by Prasanthi et al., (2013). Moderately susceptible reaction was recorded by the hybrids viz., $\mathrm{P}_{1} \times \mathrm{P}_{4}, \mathrm{P}_{3} \times \mathrm{P}_{4}$ and $\mathrm{P}_{4} \times \mathrm{P}_{1}$. Two crosses showed susceptible reaction against YMV by comparing mean score value, viz., $\mathrm{P}_{3}$ $x \mathrm{P}_{2}$ and $\mathrm{P}_{4} \times \mathrm{P}_{3}$. The inheritance of $\mathrm{YMV}$ was studied with 12 hybrids, among the hybrids, VBN $4 \times$ VBN 2, VBN $2 \times$ VBN 4 and VBN 2 x LBG 17 showed complete resistance against YMV, hence the crosses were recommended for further breeding programme to identify high yielding YMV resistant lines.

\section{Yellow Mosaic Virus disease (YMV)}

The Yellow Mosaic Virus Disease (YMV) incidence was recorded on all the plants based on the visual scores on $50^{\text {th }}$ day while the susceptible check $\mathrm{C} 05$ recorded scale 6.9. The classification was made into scales $1-9$ as follows based on the scale adopted by Singh et al., (1988).

\section{References}

Ahamad, M. 1975. Screening of mungbean (Vigna radiata) and urdbean (Vigna mungo) germplasm for resistance to yellow mosaic virus. J. Agric. Res., (Punjab), 13(1): 349-354.

Anbumalarmathi, J. 2002. Genetic analysis of yield and quality traits in greengram. M.Sc., (Ag.) Thesis, Tamil Nadu Agric. Univ., Madurai.

Baudh bharti, Rajesh kumar, H.N. Bind, Arun
Kumar and Vijaya Sharma. 2014. Correlation and path analysis for yield and yield componenets in black gram (Vigna mungo (L.) Hepper). Internat. J. Plant Sci., 9(2): 410-413

Chand, P. and J.P. Verma. 1983. Effect of yellow mosaic on growth components and yield of mungbean and urdbean. Haryana Agric. Univ. J. Res., 13: 98102.

Chauhan, M.P., A.C. Mishra and Ashok Kumar Singh. 2007. Correlation and path analysis in urdbean. Legume Res., 30(3): 205-208.

Chauhan, M.P., A.C. Mishra and Ashok Kumar Singh. 2007. Correlation and path analysis in urdbean. Legume Res., 30(3): 205-208.

Daniel, L. 1973. Methods of diallel analysis of quantitative characters and properties of plants. Acta. Univ. Agric. Fac. Agron., Boino, 21: 413-426. Genetics Abstr., 7G, 2564.

Haritha, S. and M. Reedy Sekhar. 2002. Correlation and path coefficient analysis in mungbean (Vigna radiata (L.) Wilczek). Legume Res., 25(3): 180-183.

Jalaluddin, M. and M.A.Q. Sheikh. 1981. Evaluation of mungbean (Vigna radiata (L.) Wilczek) germplasm for resistance to yellow mosaic virus. SABRAO J., 13(1): 61-68.

Kanimoli Mathivathana M., N. Shunmugavalli, A. Muthuswamy and C. Vijulan Harris. 2015. Correlation and path analysis in black gram. Agric. Sci. Digest., 35 (2):158-160.

Kasundra, J.K., K.V. Pethani and K.B. Kathiria. 1995. Studies on genetic variability, correlation and path analysis in urdbean. Indian J. Pulses Res., 8(2): 113-118.

Konda, C.R., P.H. Salimath and M.N. Mishra. 2008. Correlation and path coefficient analysis in blackgram (Vigna mungo (L.) Hepper). Legume Res., 31(3): 202- 
205.

Kousar Makeen, G. Babu Suresh, G.R. Lavany and Archana Kumari. 2009. Genetic divergence and character association in micromutants of urdbean (Vigna mungo (L.) Hepper) variety T9. Academic Journal of Plant Sciences, 2(3): 205-208.

Luman Hakim. 2008. Variability and correlation of agronomic characters of mungbean germplasm and their utilization for variety improvement program. International Journal of Agricultural Science, 9(1): 24-28.

Mallikarjuna Rao, Ch., Y. Koteswara Rao and M.V. Reddy. 2006. Evaluation of mungbean germplasm for yield and yield components. Legume Res., 29(1): 73-75.

Natarajan, C. and R. Rathinasamy. 1999. Genetic variability, correlation and path analysis in blackgram. Madras Agric. J., 86(4-6): 228-231.

Peeta Gopi, Satyanarayana A, Rama Krishna A and Sambasiva Rao KRS. 2016. Evaluation of Blackgram Germplasm for Resistance against YMV. J Plant Pathol Microbiol. 7(7): 21577471.1000368.

Prasanthi L. Reedy B.V Bhaskara, Geetha B, Jothi Ramya, Abhishek. 2013. Molecular marker for screening Yellow Mosaic disease resistance in (Vigna mungo L. Hepper). Ele. J. of Plant Breeding, 4(2): 1137-1141.

Pushpa Reni Y, Y. Koteswara Rao, Y. Satish and J. Sateesh Babu. 2013. Estimates of genetic parameters and path analysis in blackgram (Vigna mungo (L.) hepper). Inter. J. of Plant, Animal and Environmental Sciences, 3(4): 231-234.

Rahim M.A., A.A. Mia, F. Mahmud, N. Zeba and K.S. Afrin. 2010. Genetic variability, character association and genetic divergence in mungbean (Vigna radiata (L.) Wilczek). POJ., 3(1): 1-6.
Reena Mehra, A.N Tikle, Ashok Saxena, Ashok Munjal, Rekhakhandia and Mahipal Singh. 2016. Correlation, pathcoefficient and genetic diversity in Blackgram (Vigna mungo (L) Hepper), Int. Res. J. Plant Sci. 7(1): 001-011,

Sandhu, T.S. 1978. Breeding for yellow mosaic virus resistance in mungbean.in: Cowell, R.W.(ed.) Proceedings of the First International Mungbean Symposium. AVRDC, Shanhua, Tainan, Taiwan (ROC): 176-179.

Santha, S. and P. Veluswamy. 1997. Character association and path analysis in blackgram. Madras Agric. J., 84(12): 678-681.

Shamin M.Z and Pandey A. 2016. Identification of Yellow Mosaic Virus (YMV) resistant Blackgram (Vigna mungo L. Hepper) genotypes for cultivation in Northern India. Journal of Agroecology and Natural Resource Management. 1(2): 48-50.

Sheetal R. Patel, K K. Patel and Hitiksha K Parmar. 2014. genetic variability, correlation and path analysis for seed yield and its components in green gram (Vigna radiata (1.) wilczek). The Bioscan, 9(4): 1847-1852.

Singh, A.K. and S.K. Srivastava. 1985. Effect of urdbean mosaic virus infection on the yield and chemical composition of urdbean fruits. Indian Phytopath., 38: 85-89.

Singh, G., S. Kapoor and K. Singh. 1988. Multiple disease resistance in mungbean with special emphasis on mungbean yellow mosaic virus. In: International symposium on mungbean, $2^{\text {nd }}$ Nov.1620, Bangkok, Tailand, pp: 290-296.

Singh, Y.P. and R.L. Agarwal. 1998. Effect of sulphur sources and leaves on yield, nutrient uptake and quality of Urd (Vigna mungo (L.) Hepper).Indian J.Agron., 43: 448-452.

Srividhya, A., M. Reddy Sekhar, G.L.K. 
Reddy and K.S. Reddy. 2005b. Correlation and path analysis in $\mathrm{F}_{2}$ generation of urdbean (Vigna mungo (L.) Hepper). Legume Res., 28(4): 297 $-299$.

Sunil Kumar, B., S. Padmavathi, M. Prakash and J. Ganesan. 2003. Correlation and path analysis in blackgram (Vigna mungo (L.) Hepper). Legume Res., 26(1): 75-76.

Veeramani, N., M. Venkatesan, P. Thangavel and J. Ganesan. 2005. Genetic variability, heritability and genetic advance analysis in segregating generation of blackgram (Vigna mungo (L.) Hepper). Legume Res., 28(1): 49 -
51.

Vijay Kumar G, M Vanaja, P Raghu Ram Reddy, K Salini, Babu Abraham, and N Jyothi Lakshmi. 2014. Studies on Combining Ability and Genetic Advance in Blackgram (Vigna mungo). Research and Reviews: Journal of Agriculture and Allied sciences. 3(3): 14-24.

Vijiyalaxmi and A. Bhattacharya. 2006. Mungbean seed yield: III. Effect of yield attributing traits and phenology. Legume Res., 29(1): 11-17.

Williams, W. 1964. Genetic Principles and Plant breeding. Blackwell Scientific Publications, Oxford, p: 504.

\section{How to cite this article:}

Suguna, R., P. Savitha and Ananda Kumar, C.R. 2017. Correlation and Path Analysis for Yellow Mosaic Virus Disease Resistance and Yield Improvement in Blackgram [Vigna mungo (L.) Hepper]. Int.J.Curr.Microbiol.App.Sci. 6(11): 2443-2455. doi: https://doi.org/10.20546/ijcmas.2017.611.287 